\title{
Corporate Liability On Copyright
}

\author{
Melia Septiana Ketaren \\ Master of Law of Universitas Diponegoro \\ Jalan Imam Bardjo No. 1, Pleburan, Semarang Selatan, Jawa Tengah \\ melmelketaren@gmail.com
}

\begin{abstract}
Corporate crime in the field of copyright continues to grow following the economic development of a nation's society. Therefore, the application of criminal law, starting from prevention efforts through administrative legislation, criminalization, and law enforcement efforts, must always receive serious attention. Copyright is an exclusive right for the creator or recipient of the right to announce and/or reproduce his creation or give permission for it by not reducing restrictions according to the applicable laws and regulations. The granting of criminal sanctions to corporate administrators who commit copyright crimes will not give deterrent effects to the corporation, because the loss of one and/or several employees who undergo criminal sanctions can be easily replaced by anyone and at any time. The method used in this study is Normative Jurisdiction. The results of the study show that corporations in copyright infringement must be prosecuted criminally, because the losses are very large, have multi-dimensional consequences, ranging from losses to the state, the wider community of owners or copyright holders, and create frustration that weakens the spirit of creativity.
\end{abstract}

Keywords: Corporate Liability; Copyright; Criminal Sanctions

\section{A. INTRODUCTION}

The development of the corporation as a business institution turned out to be stronger along with the progress and discovery of science and technology. Corporations are of course established to make a profit. Its position as a force outside the scope of state regulation, makes corporations want to control or monopolize all economic life, without government control. This condition, according to Mohammad Mustofa, makes the corporate business at risk of harming the public interest, which is often referred to as corporate crime. The term corporate crime is often associated with crimes that are categorized as unconventional in the context of the white collar of crime, organization crime, organized crime, crime of business, syndicate crime which are generally intended as organizational crimes which lead to motives of economic profit, which reflected in the contradiction between corporate objectives and the interests of various parties such as competitors (competitors), laborers, consumers, society and the state (Yesmil \& Adang, 2010).

In connection with the scale of corporation's role in Indonesia's economy, it cannot be separated from the opportunities and concessions that has given through the laws and regulations of the authorities which detect the corruption, collusion and nepotism. For example, the new order policy (at Soeharto Era) that prioritized economic growth had resulted in giant corporations and conglomerates that 
controlled and monopolized the Indonesian economy. The extraordinary power of several giant corporations and conglomerates in the economy in the next stage is much influential in various life aspects and is very detrimental to other economic actors: consumers, among others, pricing structures; workers whose affected by policies for reducing worker's rights such as their health, safety and termination their status as employment (Burhanudin, 2013).

There are dozens of laws on the product of the country's legislation that determine and regulate criminal liability in the event of certain criminal acts which are regulated outside the Criminal Code (KUHP) which are related or deemed to be carried out and accountable by corporations, wrong one in terms of copyright.

Copyright is an exclusive right for the creator or recipient of the right to announce and/or reproduce his creation or give permission for it by not reducing restrictions according to the applicable laws and regulations. Legal protection against the wealth of art, science, culture and literature is intended as an effort to create a better climate for the growth and development of passion in the fields of science, art, culture and literature. But in the midst of increasing national development activities, especially in the fields of science, art, culture and literature, copyright infringement activities have also developed, especially in the form of piracy crimes that have reached a dangerous level and can damage the lives of the people in general and interests to create in particular.

The above violations or crimes against copyright will have a greater impact if done by a corporation that intentionally has a bad intention to reduce the maximum profit by hijacking someone's work, multiplying and trading without fulfilling the obligation as a buyer in the form of royalties to the creator and not want to pay the purchase tax and / or sales tax to the country (Mahyani, 2014).

Crime (crime) can be identified with the emergence of harm (harm), which then results in the birth of criminal liability or criminal liability. Which in turn invites debate is how corporate liability, given that in the Indonesian Criminal Code (KUHP), which is considered as the subject of criminal law, only individuals in natural biological connotations (naturlijkee person). In addition, the Criminal Code also still adheres to the principle of non potest sociates delinquere where a legal entity or corporation is considered unable to commit a criminal act. Thus, fictional thinking about the nature of legal entities (rechspersoonlijkheid) does not apply in the field of criminal law. So the development of the corporation as the subject of a crime takes place outside the Criminal Code (KUHP) with the issuance of special legislation.

The principle of corporate responsibility was first regulated in 1951, namely in the Emergency Law Number 17 of 1951 concerning Stockpiling of Goods, and is more widely known in Law No. 7 Drt of 1955 concerning Economic Crime. In the latest development, in addition to being a perpetrator, the corporation can also be held accountable for a crime (Muladi \& Priyatno, 2016). The Law Number 6 of 1982 
concerning Copyright, regulates the relationship of corporations or legal entities as perpetrators of criminal acts of copyright, as stated in Article 46. The establishment of legal entities as perpetrators of criminal acts of copyright is a step forward because Auteurswet 1912 has not yet regulated it.

In 1994, Indonesia enacted Law No.7 concerning the Ratification of the Agreement on Establishing the World Trade Organization which included the subsequent Agreement on Trade Related Aspects of Intellectual Property Rights (TRIPs). This is the form and consequence of the Indonesian state which has participated in the association of the world community by becoming a member of the international organization. In 1997, the President issued Decree No.18 which ratified the Berne Convention for the Protection of Artistic and Literary Works. In the same year, the President issued Decree No.19 concerning Ratification of the World Intellectual Property Organization Copyrights Treaty (WIPO Copyright Agreement), hereinafter referred to as WCT.

Based on the experience in implementing the existing Copyright Law, the state considers it necessary to establish a new Copyright Law, namely Law No.19 of 2002. Furthermore, in this copyright law, the title of corporation as the subject of criminal acts of copyright, no longer accommodated. For this reason, the International Intellectual Property Alliance (IIPA) recommended to the US State Trade Representative (USTR) and the World Intellectual Property Organization (WIPO) in the period 2001 to 2005 to include Indonesia in the priority watch list ranking.

The reality is that copyrighted products are often reproduced and distributed illegally, both by individuals (individuals) and corporations as legal entities. The enormous impact of corporate crime on copyright is not matched by the formulation of laws regarding corporations as the subject of criminal acts.

It is not categorized as a corporation as the subject of criminal law in this Copyright Act, resulting in corporations not being liable to criminal responsibility. Corporations that commit crimes against copyright are, as if they obtain the right of immunity, namely freedom from punishment for their crimes in the form of piracy, reproduction and trading of someone's copyright.

The regulation of corporate criminal liability in Indonesian laws and regulations is inconsistent and very sectoral. As a result of fraud and criminal acts committed by corporations, criminal penalties are imposed on corporate officials, corporate managers and employees. This does not cause a deterrent effect on the corporation, because then the corporation can still commit criminal acts after the management/officials/employees are replaced. 


\section{B. RESEARCH METHOD}

The research method used in this writing is to use normative legal research methods, using the Normative Juridical Approach. Where this normative legal research is library research (Soekanto \& Mamudji, 1985). Literature study is needed to collect legal materials needed, such as primary legal materials which include legislation governing Corporate Liability and Consumer Protection. Secondary legal materials, such as books, legal scientific works, and other written materials used to provide an explanation of some of the terms used in this writing.

\section{DISCUSSION AND ANALYSIS}

Corporate crime in the economic field continues to grow following a nation's economic growth. Therefore, the functionalization of criminal law, starting from preventive efforts through administrative legislation, criminalization, and law enforcement efforts, must always receive serious attention (Mahyani, 2014).

Perhaps the biggest loss that resulted from corporate crime in the field of copyright is the breakdown of relationships/social relationships; it is creating distrust among members of society towards existing leaders and institutions, in another side, copyright owners are lazy to create new works and kill the desire to be inspired.

The characteristics of the corporation are as follows: 1) Corporations are an association or organization that generally engages in economic activities; 2) Corporations are legal entities (rechtspersoon), and are equal to humans (natuurlijke person) as legal subjects or people; 3) Corporations as carriers of legal rights and obligations; 4) Corporations have their own assets separate from the assets of the people who are members of it; 5) Corporations have legal authority, namely the ability to carry out legal actions in the social traffic of the legal community through their organs; 6) The corporation can request and be held legally accountable, including in criminal law, so that it can be prosecuted and prosecute before the court (Adriano, 2013).

Furthermore, what are the factors that cause criminal acts/corporate crimes that result in large losses for individuals, society and the state? According to Clinard and Yeager there are two views that can be used to explain the factors that encourage the occurrence of criminal acts/corporate crimes, namely rational goals and organic models (Susanto, 1993). The first model prioritizes profit. This is the main factor or reason for committing a crime/corporate crime. Then the second model emphasizes the relationship between the company and its environment and politics, such as suppliers, competitors, consumers, government, public and other groups that are deemed relevant (Kusumo, 2008).

Starting from the principle of monodualistic thinking, the concept views that the principle of error is a pair of legality principles that must be explicitly formulated in law, in the concept of Criminal Code article 35, it reads, "accountable to the maker 
who has committed a crime" (Arief, 2008). In addition to the motivation to get the maximum benefit as reflected in the individual characteristics referred to as the anomic of success and the relationship between the corporation and its economic and political environment, Muladi adds an ineffective law enforcement system, very low criminal penalties, lack of criminality and stigmatization, deterrence, lack of social reactions through mass media and broad opportunities also strongly encouraged the occurrence of corporate crime (Salman, 1994).

Why did the government and the House of Representatives in Law No.7 of 1987 replace Act No.6 of 1982 regarding Copyright remove the provisions of corporations as subjects of criminal law? According to Ahmad Mahyani: this is a setback after our nation since 1955 considered advanced criminal law concept, especially in terms of determining the corporation as the subject of criminal law as outlined in various laws and regulations. Second: the reason for removing the provisions of the corporation as the subject of a crime as stated in the explanation in number 18 of Law No.7 of 1987 is weak and very debatable. Third: when comparing with legislation born in the era of the $80 \mathrm{~s}$ to the $90 \mathrm{~s}$, all of them adhered to the concept that corporations are subject to criminal law. Among them are Law No. 6 of 1984 concerning Posts, Law No.2 of 1992 concerning Insurance, Law No.8 of 1995 concerning Capital Markets and Law No.10 of 1995 concerning Customs (in 2006 it was changed to UU No.17) (Mahyani, 2014).

Various problems that arise related to the corporate responsibility of committing the crime for corporation are actually due to the abolition of Article 46 of the Copyright Act Number 6 of 1982 which reads "If a criminal offense as referred to in Article 44 is carried out by or in the name of a legal entity, criminal or disciplinary action is imposed on a legal entity or against a person who gives an order to do it or who leads in committing the crime ". the law was replaced with Law No.7 of 1987, which abolished article 46 of Law No. 6 of 1982 and replaced it with new article 46 of Law No.7 of 1987. In its explanation in figure number 18 of Law No.7 of 1987 states:

"Article 46 of Law No. 6 of 1982 was deleted on the basis of the consideration that those responsible for criminal acts carried out by a legal entity are administrators of that legal entity. Whether it is named the Managing Director or anything similar to that, or one of the Directors, it is usually determined in the statutes and / or bylaws of the legal entity concerned. In addition, the elimination of this provision is also intended to reach legal actions against criminal acts carried out by other bodies such as foundations ..."

This explanation is very weak and debatable by referring to the foundation as an example because the foundation is a corporation even though it does not explicitly state it, namely by using the word "Organ Foundation" instead of the word a corporation. "Other bodies" referred to in the Explanation of Number 18 of Law No. 7 of 1987 are in fact explicitly a corporation or criminal law subject such as Law No. 6 of 1984 concerning Posts, Law No.2 of 1992 concerning Insurance, Law No. .10 of 1995 in conjunction with Law No. 17 of 2006 concerning Customs, and which does 
not explicitly state, for example Law No. 36 of 1999 concerning Telecommunications, which uses the word "organizer" in place of the word a corporation (Mahyani, 2014).

Why should a corporation that infringes copyright must be prosecuted criminally? First; because the losses incurred by the corporation perpetrators of copyright crimes are very large consequences for the state and for the owner or copyright holder than if the perpetrators are individuals.

Second; Imbalance sanctions. Corporate profits are very large, causing a huge loss of society for criminal acts committed by corporations. Therefore, it is not balanced if only the administrators are convicted. For example, taken in copyright infringement committed by individuals usually by downloading other people's works both audio, visual and audio visual, with the term "crack" the serial number of the work and then use it personally and limited. The easiest copyright infringement is to buy one original product from another person in the form of audio, visual or audio visual and then burn it, then add it, used privately or limited to the environment itself.

If the copyright violator is carried out by a corporation, of course the piracy will be carried out in mass form and then traded at a cheap price so that it can sell well to get the maximum profit. For the owner or copyright holder, he does not get royalties for his hijacked work. For the country, the amount of income from the purchase tax and sales tax is very large. This is of course very disturbing and endangering the economic security of the country if in various fields of creative works such as music, publishing books, films and video recordings, and computers there is a massive piracy carried out by the corporation.

The granting of criminal sanctions to administrators will not provide deterrent effects or deterrent effects to corporations who commit copyright crimes, because the loss of one and / or several employees who undergo criminal sanctions can be easily replaced by anyone and at any time. Unlike the case if the corporation can be prosecuted criminally, in this case it is a criminal fine with the provision that the maximum fine is added to one third. Or by imposing a criminal fine against the corporation with threefold weighting, adopting Law No.24 of 2007 concerning Disaster Management Article 79 paragraph (1). Thus the corporation will be subject to criminal penalties as stated in nominal value in Article 72 paragraph (1) Copyright Act No. 19 of 2002 worth five billion rupiahs in threefold amounts, so that the penalty amount is fifteen billion rupiahs. That amount must be paid by the corporation to the state.

The imposition of severe penalties needs to be applied because copyright crimes which are part of a definite economic crime are motivated by economic reasons. Unfortunately, the penalties dropped so far are often too small. A penalty will only be effective as a deterrent if the potential yield or profit is smaller than the weight of the penalty or the possibility of being caught. Corporations that plan to hijack copyrighted works with a target profit of one hundred million rupiahs, for example, 
and have calculated that they have a $10 \%$ chance of being caught, will cancel their bad intentions if they know that the risk will be in the form of a fine of fifteen billion.

Furthermore, those who must be responsible in the corporation are charged with the highest imprisonment and / or criminal penalties. In order to be able to keep up with the developments in the value of money fines, it should apply a system of categories such as the concept of the New Criminal Code. For the owner or copyright holder whose rights are violated by the corporation, the judge can be able to impose additional criminal sanctions on the corporation concerned in the form of the obligation to pay compensation to the victim. Judges can also consider dropping other additional penalties in the form of revocation of business licenses and / or revocation of legal status if the violations committed have been repeated and incur large losses.

When the court has sentenced the corporation and its administrators to be sentenced, it is believed that this will lead to a deterrent effect, can prevent a repeat of copyright infringement later, given the amount of the fine and / or the length of the imprisonment that the perpetrator must undergo. Actors or corporations will think twice if they want to infringe on copyright, because a very large risk must be borne if their crimes are revealed. In contrast to the current situation, where the calculation of profit by violating copyright is very large compared to the risk of punishment that will be accepted. Business people in the field of audio, visual, audio visual, book publishing, computers and IT may be motivated to commit copyright infringement considering that the sangs are light and can be tricked.

Another obstacle in imposing harsh criminal sanctions on corporations or perpetrators of violating copyright, in addition to the law which does not stipulate that corporations can be prosecuted, is also influenced by the tendency to use subsidiarity principles, namely criminal law placed in its position as ultimum remidium.

According to Suprapto, corporations can be blamed if intentional or negligent or negligent lies in people who become corporate tools. Errors are not individual but collective (Setiyono, 2002). This is in line with the opinion of Van Bemmelen and Remmelink, which states that corporations can still have errors with the construction of errors of management or members of the board of directors. In connection with this, Roeslan Saleh argues that the principle of error in the corporation is not absolutely valid, but that it is sufficient to base the legal adverts on the loquitur (the facts speak for themselves) (Muladi \& Priyatno, 1991). Actually this is no stranger because Anglo Saxon countries are known as the mens rea (inner attitude) with exceptions to certain offenses, namely what is known as strict liability and vicarious liability.

Strict liability is a criminal liability without having to prove a mistake. The principle of responsibility that views error as something that is irrelevant to the problem is whether it exists or does not exist. According to this doctrine, someone can 
be accounted for a particular crime even though there is no mistake in that person. According to LB Curson, this doctrine is based on certain reasons, which are (Kristian, 2013):

1. It is very essential to ensure that certain important rules are required for social welfare.

2. Proof of the existence of mens rea will be very difficult for violations related to social welfare.

3. The high social level caused by the action concerned.

Meanwhile, according to Ted Honderich, strict liability is used for the following reasons (Kristian, 2013):

1. The difficulty of proving accountability for certain crimes.

2. It is very necessary to prevent certain types of criminal acts from avoiding very extensive dangers.

3. Penalties imposed as a result of strict liability are very mild.

In countries that adhere to the Common Law system, strict liability applies to three types of offenses, namely:

1. Public Nuisance, interference with public order, blocking the highway, producing unpleasant odors.

2. Criminal Libel, slander, defamation.

3. Contemptof court, violation of court rules.

But most strict liability is found in statutory offenses, regulatory offenses, mala prohibita, which generally constitute offenses against public welfare. Including regulatory offenses such as the sale of food and beverages or drugs that are harmful, the use of misleading trade images and traffic violations.

Vicarious Liability is a criminal responsibility imposed on someone for the actions of others. Such accountability, for example, occurs in the event that the actions performed by another person are within the scope of work or position. Generally, it is limited to cases involving relations between the employer and his workers, servants or subordinates.

Corporations can be accounted for on the basis of the two doctrines in its development is indeed very necessary. Because with the development of technology, it is not easy to get sufficient evidence about the mistakes of corporate owners. In connection with this, Barda Nawawi Arief stated that the two doctrines mentioned above need to be considered to the extent that they can be taken operatively. This is related to several current criminal acts that are closely related to developments and advancements in the fields of technology, economy and trade which involve many legal entities or corporations. Especially if the consequences of these offenses involve the public interest. It is very difficult to prove the existence of a mistake in the corporation because in general those who have errors are people. To make it easier 
to consider the corporate criminal liability system with the principle or doctrine of strict liability and vicarious liability (Arief, 2010).

In the Criminal Law (Criminal Law Concepts) doctrine of strict liability and vicarious liability is accepted. For a strict liability can be found in Article 35 paragraph (2) stating: For certain criminal acts, the law may determine that a person may be prosecuted solely for the fulfillment of such elements of the offense without regard to the offense. Furthermore, for the vicarious liability can be seen in Article 35 verse (3) stating that in any case, any person may be liable for any offense committed by another person, if specified in a law.

This corporate criminal liability can also be seen in Article 49 of the 2015 Criminal Code Bill which states "Criminal acts are committed by corporations if carried out by people who have functional positions in corporate organizational structures acting for and on behalf of corporations or for corporate interests, based on work relations or based on other relationships, within the scope of the corporation's business, either individually or together". Furthermore, Article 50 of the Criminal Code Bill states that "If a criminal act is committed by a corporation, criminal liability is imposed on the corporation and/or its management or corporate controlling personnel". Furthermore in Article 51 of the Criminal Code Bill stated that "Corporations can be criminally accountable for an act committed for and/or on behalf of a corporation, if the action is included in the scope of its business as specified in the articles of association or other provisions applicable to the corporation concerned "Whereas the restrictions are regulated in Article 52 of the Criminal Code Bill which says "The criminal liability of corporate managers is limited as long as the management has a functional position in the corporate organizational structure".

With regard to corporate responsibility in criminal law, is the sanction / criminal more appropriate to be imposed on the corporation? In my opinion, the most appropriate is criminal penalties, from the principal crimes available. In addition to criminal penalties, corporations are also subject to additional penalties in the form of revocation of rights obtained by corporations, announcement of judge's decisions, civil sanctions in the form of compensation for the consequences of corporate crime. Except that, corporations can also be subject to disciplinary measures, namely the placement of companies under the supervision of the authorities within a certain period of time. Especially regarding the revocation of the rights obtained by the corporation, restrictions are needed. If what is meant by revocation is the revocation of an operational permit, what must be considered are the consequences that may arise due to the sanction. Because, revocation of operational licenses is tantamount to closing the company, so that the most affected are employees or laborers compared to the businessman or company owner. In view of this, the punishment of corporations is done carefully or selectively, because the impact is very broad. Those who suffer not only do wrong, but other innocent parties such as employees or laborers, shareholders and the public or consumers suffer. 


\section{CONCLUSION}

Corporations in copyright must be categorized or criminalized as subjects of criminal law that can be prosecuted for their actions in the form of crimes against copyright. Because this is indeed the development of modern criminal law.

Remembering also that the development of criminal law since 1909 in the United States and 1950 in the Netherlands has stated that corporations are subject to criminal law. In Indonesia itself has been known since 1951 in the Stockpiling Law. Besides that, there are thirty-two laws which state that corporations are the subject of criminal law and that many countries today recognize that corporations are legal subjects in criminal law. We should Indonesian people adhere to this opinion as a consequence of the adaptive nature of criminal law.

Corporations in copyright infringement must be prosecuted criminally, because the losses caused are very large, have multi-dimensional consequences, ranging from losses to the state, the wider community of owners or copyright holders, frustration which weakens the spirit of creation which ultimately impacts the country's economy especially in the field of copyright. Considering that all this time the sanctions imposed only on corporate managers who have proven unsuccessful have caused a deterrent effect.

It is recommended that the system of sanctions against corporations in criminal acts of copyright be cumulative which adheres to the double track system. This needs to be considered because the parties behind the corporation are very complex. The imposition of sanctions on corporations not only affects the corporation concerned, but also on workers or employees or people whose lives depend on the corporation.

\section{REFERENCES}

Adriano. (2013). Menguji Konsep Pertanggungjawaban Pidana Korporasi. Yuridika.

Arief, B. N. (2008). Bunga Rampai Kebijakan Hukum Pidana, Perkembangan Penyusunan KUHP Baru. Jakarta: Kencana Prenada Media Group.

Arief, B. N. (2010). Perbandingan Hukum Pidana. Jakarta: Rajawali Press.

Burhanudin. (2013). Tindak Pidana Korupsi Sebagai Kejahatan Korporasi. Jurnal Cita Hukum, 1(1), 75-84.

Kristian. (2013). Urgensi Pertanggungjawaban Pidana Korporasi. Jurnal Hukum \& Pembangunan, 44(4), 575-621.

Kusumo, B. A. (2008). Pertanggungjawaban Korporasi dalam Hukum Pidana di Indonesia. Jurnal Wacana Hukum, VII(2), 52-65.

Mahyani, A. (2014). Pertanggungjawaban Pidana Korporasi Terhadap Hak Cipta. DIH Jurnal Ilmu Hukum, 10(20), 83-93.

Muladi, \& Priyatno, D. (1991). Pertanggungjawaban Korporasi Dalam Hukum Pidana. Bandung: Sekolah Tinggi Hukum Bandung.

Muladi, \& Priyatno, D. (2016). Pertanggungjawaban Pidana Korporasi. Jakarta: Prenamedia. 
Salman, L. (1994). Anatomi Kejahatan Korporasi dan Penanggulangannya. Yogyakarta: Fakultas Hukum Universitas Islam Indonesia. Setiyono. (2002). Kejahatan Korporasi. Malang: Averroes Press.

Soekanto, S., \& Mamudji, S. (1985). Penelitian Hukum Normatif: Suatu Tinjauan Singkat. Jakarta: Rajawali.

Susanto, I. S. (1993). Kriminologi. Semarang: Fakultas Hukum Universitas Diponegoro. Yesmil, A., \& Adang. (2010). Kriminologi. Bandung: Refika Aditama. 